\title{
Response of Cauliflower (Brassica oleracea var. Botrytis) to the Application of Boron and Phosphorus in the Soils of Rupandehi District
}

\author{
Dhruba Dhakal ${ }^{1}$, Shree C. Shah ${ }^{2}$, Durga M. Gautam² and Rama N. Yadav ${ }^{2}$ \\ ${ }^{1}$ Soil Management Directorate, Department of Agriculture, Hariharbhawan, Lalitpur \\ ${ }^{2}$ Institute of Agriculture and Animal Science, Tribhuvan University, Rampur, Chitwan, \\ Nepal
}

\begin{abstract}
A field experiment was conducted at Paklihawa Campus of the Institute of Agriculture and Animal Science, Rupandehi, Nepal, during Oct 2004 to Feb 2005 to study the effects of boron and phosphorus on the soil nutrient status, nutrient uptake by plant and yield of cauliflower (Brassica oleracea var. botrytis L.) variety Snowball-16. Sixteen treatment combinations, including four levels of boron $\left(0,0.65,1.3,1.95 \mathrm{~kg}\right.$ boron $\left.\mathrm{ha}^{-1}\right)$ and four levels of phosphorus $\left(0,30,60,90 \mathrm{~kg}_{2} \mathrm{O}_{5}\right.$ ha $\left.^{-1}\right)$ were included. The soil was loamy with very low in boron. Curd yield, harvest index, boron and phosphorus uptake by plant and available boron in soil were significantly increased by the application of boron and phosphorus in soils. Available phosphorus in soils after the crop harvest was significantly increased by phosphorus application. The highest curd yield, boron and phosphorus uptake by plant as well as available boron and phosphorus in soils after the crop harvest were obtained from the application of $1.3 \mathrm{~kg}$ boron with $60 \mathrm{~kg} \mathrm{P}_{2} \mathrm{O}_{5} \mathrm{ha}^{-1}$. The boron uptake by plant was decreased by the application of more than $1.3 \mathrm{~kg}$ boron $\mathrm{ha}^{-1}$ while the phosphorus uptake was increased with increased application of phosphorus upto $90 \mathrm{~kg} \mathrm{P}_{2} \mathrm{O}_{5} \mathrm{ha}^{-1}$. There were quadratic responses of curd yield, harvest index and plant boron uptake to the applied boron; quadratic response of plant phosphorus uptake to the applied phosphorus, while responses of curd yield, and harvest index to the applied phosphorus were linear. Highly significant positive correlations between curd yield and leaf boron content $\left(\mathrm{r}=0.68^{* *}\right)$ as well as curd yield and plant phosphorus content $\left(\mathrm{r}=0.79^{* *}\right)$ were observed. In conclusion, the combined application of $1.3 \mathrm{~kg}$ boron and $60 \mathrm{~kg} \mathrm{P}_{2} \mathrm{O}_{5} \mathrm{ha}^{-1}$ was found to be the best for cauliflower production under Paklihawa soil conditions of Rupandehi district and can be recommended to the growers of this region.
\end{abstract}

Key words: Borax, Brassica oleracea var. botrytis, curd yield, phosphorus

\section{INTRODUCTION}

Cauliflower is an economically important winter vegetable of Nepal. It is nutritionally rich and has medicinal value. The agro-climatic conditions across the country favor the production of cauliflower even in summer season with export potentiality. From production aspect, it requires balanced dose of plant nutrients, particularly nitrogen, phosphorus, potassium, boron and molybdenum (Mengel and Kirkby 1987). The productivity of cauliflower is not satisfactory due to poor soil fertility and imbalanced fertilization. Micronutrients deficiency is more prevalent in Nepalese soils (Fujimoto 
1998, Jaishy et al 2000). The deficiency of boron causes browning and bitterness of curd with hollow stem. Similarly, poor root growth, delayed crop maturity and curd quality deterioration are caused by phosphorus deficiency (Mitra 1990). Boron deficiency is commonly found in sandy loam soils due to more leaching of this element; therefore, its problem is more prevalent in Rupandehi district. Due to soil alkalinity, phosphorus fixation by soil constituents is another problem of the area.

Although several studies have been conducted on boron and phosphorus requirements of cauliflower in the various parts of the world, there is limited information under Nepalese soil conditions on this aspect. Moreover, no research work has been reported on the effects of boron and phosphorus in cauliflower production in the Rupandehi district. The present research, therefore was conducted to determine the effects of different doses of boron and phosphorus on the nutrient status, uptake and yield of cauliflower.

\section{MATERIALS AND METHODS}

\section{TREATMENT DETAILS}

The experiment was conducted at Horticulture farm of Institute of Agriculture and Animal Science, Paklihawa Campus, Rupandehi, Nepal. Field experiment was conducted during Oct 2004 to Feb 2005 in a randomized complete block design consisting of 16 treatment combinations with three replications. Individual plot size was $6.75 \mathrm{~m}^{2}\left(3 \times 2.25 \mathrm{~m}^{2}\right)$ having 25 plants. The test crop was cauliflower of variety Snowball-16. The treatment combinations were $0,0.65,1.3,1.95 \mathrm{~kg} \mathrm{~B} \mathrm{ha}^{-1}$ and $0,30,60,90 \mathrm{~kg} \mathrm{P}_{2} \mathrm{O}_{5} \mathrm{ha}^{-1}$. Boron was applied through Borax $(11 \% \mathrm{~B})$ and phosphorus through single super phosphate $\left(16 \% \mathrm{P}_{2} \mathrm{O}_{5}\right)$. The recommended dose of nitrogen was applied through urea and potassium through muriate of potash. Half dose of nitrogen, full dose of phosphorus and potassium and $70 \%$ of boron were incorporated into the soil at the time of seedling transplanting. Remaining $30 \%$ boron was applied as a foliar spray of $0.4 \%$ boron solution at two months after seedling transplanting. Remaining amount of nitrogen was split into two equal parts and each part was top dressed at one and two months after transplanting.

Table 1. Treatment combinations used for the field experiment

\begin{tabular}{lccl}
\hline \multirow{2}{*}{ Treatment no. } & \multicolumn{3}{c}{ Treatment combinations } \\
\cline { 2 - 3 } & Boron $(\mathrm{B}), \mathrm{kg} \mathrm{ha}^{-1}$ & Phosphorus $\left(\mathrm{P}_{2} \mathrm{O}_{5}\right), \mathrm{kg} \mathrm{ha}^{-1}$ & Symbol \\
\hline $\mathrm{T}_{1}$ & 0 & 0 & $\mathrm{~B}_{0} \mathrm{P}_{0}$ \\
$\mathrm{~T}_{2}$ & 0 & 30 & $\mathrm{~B}_{0} \mathrm{P}_{30}$ \\
$\mathrm{~T}_{3}$ & 0 & 60 & $\mathrm{~B}_{0} \mathrm{P}_{60}$ \\
$\mathrm{~T}_{4}$ & 0 & 90 & $\mathrm{~B}_{0} \mathrm{P}_{90}$ \\
$\mathrm{~T}_{5}$ & 0.65 & 0 & $\mathrm{~B}_{0.65} \mathrm{P}_{0}$ \\
$\mathrm{~T}_{6}$ & 0.65 & 30 & $\mathrm{~B}_{0.65} \mathrm{P}_{30}$ \\
$\mathrm{~T}_{7}$ & 0.65 & 60 & $\mathrm{~B}_{0.65} \mathrm{P}_{60}$ \\
$\mathrm{~T}_{8}$ & 0.65 & 90 & $\mathrm{~B}_{0.65} \mathrm{P}_{90}$ \\
$\mathrm{~T}_{9}$ & 1.30 & 0 & $\mathrm{~B}_{1.3} \mathrm{P}_{0}$ \\
$\mathrm{~T}_{10}$ & 1.30 & 30 & $\mathrm{~B}_{1.3} \mathrm{P}_{30}$ \\
$\mathrm{~T}_{11}$ & 1.30 & 60 & $\mathrm{~B}_{1.3} \mathrm{P}_{60}$ \\
$\mathrm{~T}_{12}$ & 1.30 & 90 & $\mathrm{~B}_{1.3} \mathrm{P}_{90}$ \\
$\mathrm{~T}_{13}$ & 1.95 & 0 & $\mathrm{~B}_{1.95} \mathrm{P}_{0}$ \\
$\mathrm{~T}_{14}$ & 1.95 & 30 & $\mathrm{~B}_{1.95} \mathrm{P}_{30}$ \\
$\mathrm{~T}_{15}$ & 1.95 & 60 & $\mathrm{~B}_{1.95} \mathrm{P}_{60}$ \\
$\mathrm{~T}_{16}$ & 1.95 & 90 & $\mathrm{~B}_{1.95} \mathrm{P}_{90}$ \\
\hline
\end{tabular}




\section{SOIL SAMPLING AND LABORATORY ANALYSIS}

Composite soil samples from each block were taken before transplanting of cauliflower seedlings. The samples were air-dried and sieved through $2 \mathrm{~mm}$ for analysis. Nitrogen, phosphorus, potassium and boron were analyzed by Kjeldahl distillation unit (Bremmer and Mulvaney 1982), Olsen's bicarbonate (Olsen et al 1954), Ammonium acetate (Pratt 1965) and Azomethine-H (Gaines and Mitchell 1979) methods, respectively. Organic matter content (Walkley and Black 1934), soil texture by hydrometer (Gee and Bauder 1986) and soil $\mathrm{pH}$ by digital $\mathrm{pH}$ meter were analyzed.

Table 2. Physico-chemical properties of the soil before the field experiment

\begin{tabular}{|c|c|c|c|c|c|c|c|c|c|c|}
\hline Rep & $\begin{array}{c}\mathrm{OM}, \\
\%\end{array}$ & $\begin{array}{c}\text { Total N, } \\
\%\end{array}$ & $\begin{array}{c}\mathrm{P}_{2} \mathrm{O}_{5}, \mathrm{~kg} \\
\mathrm{ha}^{-1}\end{array}$ & $\begin{array}{c}\mathrm{K}_{2} \mathrm{O}, \mathrm{kg} \\
\mathrm{ha}^{-1}\end{array}$ & $\begin{array}{l}\mathrm{B}(\mu \mathrm{g} \\
\left.\mathrm{gm}^{-1}\right)\end{array}$ & $\mathrm{pH}$ & $\begin{array}{c}\text { Sand, } \\
\%\end{array}$ & $\begin{array}{c}\text { Silt, } \\
\%\end{array}$ & $\begin{array}{c}\text { Clay, } \\
\%\end{array}$ & $\begin{array}{c}\text { Soil textural } \\
\text { class }\end{array}$ \\
\hline 1 & 1.27 & 0.126 & 196.7 & 156.9 & $<0.1$ & 7.7 & 45 & 38 & 17 & Loam \\
\hline 2 & 1.19 & 0.118 & 200.3 & 144.6 & $<0.1$ & 7.6 & 43 & 40 & 17 & Loam \\
\hline 3 & 1.24 & 0.141 & 185.0 & 148.7 & $<0.1$ & 7.6 & 44 & 39 & 17 & Loam \\
\hline
\end{tabular}

After the crop harvesting, the composite soil samples from each plot were sampled and were analyzed for boron and available phosphorus by using Azomethine-H (Gaines and Mitchell 1979) and Olsen's Bicarbonate (Olsen et al 1954), respectively. Plant samples from each plot were analyzed for total boron and phosphorus using Azomethine-H (Gaines and Mitchell 1979) and vanadomolybdophosphoric yellow (Moore 1991), respectively.

\section{DATA OBSERVATION AND STATISTICAL ANALYSIS}

Fresh weight of total biomass and curd weight were taken from central nine plants from each plot. The analysis of variance followed by DMRT (Duncan's Multiple Range Test) was used to analyze the data and to separate the means. Correlation analysis was used to show the relationship between yield and yield parameters. The data analysis procedures were followed as described by Gomez and Gomez (1984) using MSTATC, Minitab and MS-Excel.

\section{RESULTS AND DISCUSSION}

\section{Curd yield}

The boron and phosphorus and their interaction effects in relation to curd yield were highly significant (Table 3). The individual effect of boron on curd yield was the highest (19.44 $\mathrm{mg} \mathrm{ha}^{-1}$ ) at $\mathrm{B}_{1.3}$ level, which was significantly greater than $\mathrm{B}_{1.9}$ and $\mathrm{B}_{0}$ levels but similar to $\mathrm{B}_{0.65}$. Like this $\mathrm{P}_{90}$ level had the highest (17.07 mg ha ${ }^{-1}$ ) curd yield which was significantly higher than $\mathrm{P}_{30}$ and $\mathrm{P}_{0}$ levels but at par with $\mathrm{P}_{60}$. The curd yield was highly correlated with plant phosphorus uptake $\left(\mathrm{r}=0.79^{* *}\right)$ and leaf boron $\left(\mathrm{r}=0.68^{* *}\right)$ uptake. The curd yield was increased upto $\mathrm{B}_{1.3}$ levels of boron application into soil while it was decreased at $\mathrm{B}_{1.95}$ level. Similarly, the curd yield was increased from $\mathrm{P}_{0}$ to $\mathrm{P}_{90}$ levels of phosphorus application. The maximum curd yield $\left(26.47 \mathrm{mg} \mathrm{ha}^{-1}\right)$ was found from $\mathrm{B}_{1.3} \mathrm{P}_{60}$, which was similar to $\mathrm{B}_{1.3} \mathrm{P}_{90}, \mathrm{~B}_{1.95} \mathrm{P}_{30}$ and $\mathrm{B}_{1.95} \mathrm{P}_{90}$ levels of boron and phosphorus application. 
Nepal Agric. Res. J. Vol. 9, 2009

Table 3. Curd yield response of cauliflower to applied boron and phosphorus

\begin{tabular}{lrrrrr}
\hline \multirow{2}{*}{ Treatments } & \multicolumn{5}{c}{ Curd yield, $\mathrm{mg} \mathrm{ha}^{-1}$} \\
\cline { 2 - 6 } & $\mathrm{P}_{0}$ & $\mathrm{P}_{30}$ & \multicolumn{1}{c}{$\mathrm{P}_{60}$} & $\mathrm{P}_{90}$ & Mean \\
\hline $\mathrm{B}_{0}$ & $9.65 \mathrm{f}$ & $9.44 \mathrm{f}$ & $14.99 \mathrm{e}$ & $17.07 \mathrm{de}$ & $12.79 \mathrm{c}$ \\
$\mathrm{B}_{0.65}$ & $16.69 \mathrm{de}$ & $15.73 \mathrm{e}$ & $20.58 \mathrm{c}$ & $22.46 \mathrm{bc}$ & $18.86 \mathrm{~b}$ \\
$\mathrm{~B}_{1.3}$ & $19.44 \mathrm{~cd}$ & $22.58 \mathrm{bc}$ & $26.47 \mathrm{a}$ & $26.24 \mathrm{a}$ & $22.29 \mathrm{a}$ \\
$\mathrm{B}_{1.95}$ & $14.53 \mathrm{e}$ & $25.65 \mathrm{ab}$ & $20.88 \mathrm{c}$ & $24.73 \mathrm{ab}$ & $22.85 \mathrm{a}$ \\
\hline Mean & $15.08 \mathrm{D}$ & $18.35 \mathrm{C}$ & $20.73 \mathrm{~B}$ & $22.63 \mathrm{~A}$ & 19.19 \\
SEM (0.05) & $\mathrm{B} * \mathrm{P} 1.094$ & $\mathrm{~B} 0.54$ & $\mathrm{P} 0.54$ & & \\
LSD (0.05) & 3.159 & 1.58 & 1.58 & & \\
CV, \% & 9.87 & & & & \\
\hline
\end{tabular}

Means followed by the same letter(s) in column and row are not significantly different at $5 \%$ level.

Curd yield responded linearly to boron and phosphorus applications (Figure 1a, 1b). Similar findings were also reported by Baral et al (1986) that application of $60 \mathrm{~kg} \mathrm{P}_{2} \mathrm{O}_{5}$ along with $1.5 \mathrm{~kg}$ boron ha ${ }^{-1}$ increased the total curd weight, curd size and marketable curd yield. Soil application of borax at the rate of $20 \mathrm{~kg} \mathrm{ha}^{-1}$ increased curd yield (Mishra 1972, Thakur et al 1991). The results were in agreement with the finding of Pandey et al (1974) and Randhawa and Bhail (1976). The increase in yield might be due to synergistic interaction effects between applied boron and phosphorus in the soil.

\section{Harvest index}

The phosphorus application to soil had no significant effect on harvest index of cauliflower but applied boron and their interaction effects were found to be significant (Table 4). The maximum harvest index $(49.14 \%)$ was obtained from $\mathrm{B}_{1.95} \mathrm{P}_{30}$ which was similar to all treatments except control, $\mathrm{B}_{0} \mathrm{P}_{30}$, and $\mathrm{B}_{0} \mathrm{P}_{60}$. The harvest index with applied boron had quadratic relationship (Figure 1c) while with applied phosphorus had linear (Figure 1d). The mean harvest index was increased from $\mathrm{B}_{0}$ to $\mathrm{B}_{1.95}$ and $\mathrm{B}_{1.95}(39.9 \%)$ was significantly higher than $\mathrm{B}_{0}$ while it was similar to $\mathrm{B}_{0.65}$ and $\mathrm{B}_{1.3}$ levels.

Table 4. Harvest index of cauliflower as affected by boron and phosphorus application

\begin{tabular}{lrrrrr}
\hline \multirow{2}{*}{ Treatments } & \multicolumn{5}{c}{ Harvest index, \% } \\
\cline { 2 - 6 } & \multicolumn{1}{c}{$\mathrm{P}_{0}$} & \multicolumn{1}{c}{$\mathrm{P}_{30}$} & \multicolumn{1}{c}{$\mathrm{P}_{60}$} & \multicolumn{1}{c}{$\mathrm{P}_{90}$} & Mean \\
\hline $\mathrm{B}_{0}$ & $28.14 \mathrm{~cd}$ & $22.85 \mathrm{~d}$ & $31.93 \mathrm{bcd}$ & $46.08 \mathrm{ab}$ & $32.25 \mathrm{~b}$ \\
$\mathrm{~B}_{0.65}$ & $39.56 \mathrm{abc}$ & $37.81 \mathrm{abcd}$ & $42.30 \mathrm{abc}$ & $34.54 \mathrm{abcd}$ & $38.55 \mathrm{ab}$ \\
$\mathrm{B}_{1.3}$ & $41.55 \mathrm{abc}$ & $39.39 \mathrm{abc}$ & $36.26 \mathrm{abcd}$ & $40.16 \mathrm{abc}$ & $39.34 \mathrm{ab}$ \\
$\mathrm{B}_{1.95}$ & $33.76 \mathrm{abcd}$ & $49.14 \mathrm{a}$ & $40.05 \mathrm{abc}$ & $36.67 \mathrm{abcd}$ & $39.90 \mathrm{a}$ \\
\hline Mean & $35.75 \mathrm{~ns}$ & $37.30 \mathrm{~ns}$ & $37.64 \mathrm{~ns}$ & $39.36 \mathrm{~ns}$ & 37.51 \\
$\mathrm{SEM}(0.05)$ & $\mathrm{B} * \mathrm{P} 4.719$ & $\mathrm{~B} 2.36$ & $\mathrm{P} 2.36$ & & \\
LSD $(0.05)$ & 3.63 & 6.81 & 6.81 & & \\
$\mathrm{CV}, \%$ & 21.79 & & & & \\
\hline
\end{tabular}

Means followed by the same letter(s) in column and row are not significantly different at $5 \%$ level. 


\section{Boron uptake}

The applied boron and phosphorus as well as their interaction effects were highly significant on boron uptake by plant (Table 5 and 6). The individual effect of applied boron on boron uptake by leaf and curd were the highest $\left(19.5 \mu \mathrm{g} \mathrm{gm}^{-1}\right.$ and $\left.17.75 \mu \mathrm{g} \mathrm{gm}^{-1}\right)$ at $\mathrm{B}_{1.3}$ level and it was significantly higher than $\mathrm{B}_{1.95}, \mathrm{~B}_{0.65}$ and $\mathrm{B}_{0}$ levels. Like this, the individual effect of applied phosphorus on boron uptake by leaf was the highest $\left(4.33 \mu \mathrm{g} \mathrm{gm}^{-1}\right)$ at $\mathrm{P}_{30}$ level and it was significantly higher than $\mathrm{P}_{90}, \mathrm{P}_{60}$ and $\mathrm{P}_{0}$ levels. The $\mathrm{B}_{1.3}$ had the highest mean boron uptake by leaf $\left(20.22 \mu \mathrm{g} \mathrm{gm}^{-1}\right)$ and curd $(17.6 \mu \mathrm{g}$ $\mathrm{gm}^{-1}$ ) which were significantly higher than $\mathrm{B}_{1.95}, \mathrm{~B}_{0.65}$ and $\mathrm{B}_{0}$ levels. Similarly, among the different levels of phosphorus, $\mathrm{P}_{60}$ had the highest mean boron uptake by leaf $\left(14.29 \mu \mathrm{g} \mathrm{gm}^{-1}\right)$ and curd $(17.12$ $\mu \mathrm{gm}^{-1}$ ) which were significantly higher than other levels of phosphorus including control. The highest boron uptake by plant leaf and curd were recorded at $\mathrm{B}_{1.3} \mathrm{P}_{60}$. The boron uptake by plant leaf and curd was increased with increasing levels of boron upto $\mathrm{B}_{1.3}$ and phosphorus upto $\mathrm{P}_{60}$ levels, and then it was decreased. The curd boron content was correlated $\left(\mathrm{r}=0.5^{*}\right)$ and leaf B content was highly correlated $\left(\mathrm{r}=0.66^{* *}\right)$ with phosphorus content of plant. The curd boron was also highly correlated $\left(\mathrm{r}=0.63^{* *}\right)$ with leaf boron. The boron uptake by cauliflower leaf and curd with applied boron had quadratic relationship (Figure 1e, 1f).

Table 5. Boron uptake by cauliflower leaf as affected by boron and phosphorus fertilization

\begin{tabular}{lccccc}
\hline \multirow{2}{*}{ Treatments } & \multicolumn{5}{c}{ Boron uptake by leaf, $\mu \mathrm{g} \mathrm{gm}{ }^{-1}$} \\
\cline { 2 - 5 } & \multicolumn{1}{c}{$\mathrm{P}_{0}$} & $\mathrm{P}_{30}$ & \multicolumn{1}{c}{$\mathrm{P}_{60}$} & $\mathrm{P}_{90}$ & Mean \\
\hline $\mathrm{B}_{0}$ & $1.98 \mathrm{~m}$ & 4.331 & $0.65 \mathrm{p}$ & $1.66 \mathrm{n}$ & $2.157 \mathrm{~d}$ \\
$\mathrm{~B}_{0.65}$ & $11.15 \mathrm{~h}$ & $8.66 \mathrm{i}$ & $8.00 \mathrm{j}$ & $1.02 \mathrm{o}$ & $7.208 \mathrm{c}$ \\
$\mathrm{B}_{1.3}$ & $19.50 \mathrm{~d}$ & $17.67 \mathrm{e}$ & $26.82 \mathrm{a}$ & $22.00 \mathrm{~b}$ & $20.22 \mathrm{a}$ \\
$\mathrm{B}_{1.95}$ & $5.00 \mathrm{k}$ & $11.74 \mathrm{~g}$ & $21.70 \mathrm{c}$ & $15.19 \mathrm{f}$ & $14.69 \mathrm{~b}$ \\
\hline Mean & $9.40 \mathrm{D}$ & $10.60 \mathrm{~B}$ & $14.29 \mathrm{~A}$ & $9.96 \mathrm{C}$ & 11.06 \\
$\mathrm{SEM}(0.05)$ & $\mathrm{B} * \mathrm{P} 0.044$ & $\mathrm{~B} 0.022$ & $\mathrm{P} 0.022$ & & \\
$\mathrm{LSD}(0.05)$ & 0.129 & 0.064 & 0.064 & \\
$\mathrm{CV}, \%$ & 6.7 & & &
\end{tabular}

Table 6. Effects of boron and phosphorus on boron uptake by cauliflower curd

\begin{tabular}{lcccrr}
\hline \multirow{2}{*}{ Treatments } & \multicolumn{5}{c}{ Boron uptake by curd, $\mu \mathrm{g}$ gm $^{-1}$} \\
\cline { 2 - 6 } & $\mathrm{P}_{0}$ & $\mathrm{P}_{30}$ & $\mathrm{P}_{60}$ & \multicolumn{1}{c}{$\mathrm{P}_{90}$} & Mean \\
\hline $\mathrm{B}_{0}$ & 5.331 & $6.71 \mathrm{k}$ & $11.07 \mathrm{i}$ & $4.03 \mathrm{~m}$ & $6.78 \mathrm{~d}$ \\
$\mathrm{~B}_{0.65}$ & $11.41 \mathrm{~h}$ & $10.93 \mathrm{i}$ & $14.41 \mathrm{f}$ & $9.37 \mathrm{j}$ & $11.53 \mathrm{c}$ \\
$\mathrm{B}_{1.3}$ & $17.75 \mathrm{~d}$ & $13.72 \mathrm{~g}$ & $23.51 \mathrm{a}$ & $17.26 \mathrm{e}$ & $17.60 \mathrm{a}$ \\
$\mathrm{B}_{1.95}$ & $11.03 \mathrm{i}$ & $13.74 \mathrm{~g}$ & $19.47 \mathrm{c}$ & $21.68 \mathrm{~b}$ & $16.94 \mathrm{~b}$ \\
\hline Mean & $11.3 \mathrm{C}$ & $11.28 \mathrm{C}$ & $17.12 \mathrm{~A}$ & $13.55 \mathrm{~B}$ & 13.21 \\
SEM (0.05) & $\mathrm{B} * \mathrm{P} 0.079$ & $\mathrm{~B} 0.039$ & $\mathrm{P} 0.039$ & & \\
LSD (0.05) & 0.229 & 0.114 & 0.114 & \\
CV, \% & 10.3 & & &
\end{tabular}

The result confirmed the earlier work of Gupta (1993) that optimum level of soil phosphorus increased the boron uptake by cauliflower. Similar findings were also reported by Stoyanov (1971) that optimum level of phosphorus supply increased the boron uptake by plant. Kotur and Kumar (1989) also showed a positive response of added phosphorus on boron uptake by cauliflower.

\section{Phosphorus uptake}

The individual as well as interaction effects of applied boron and phosphorus on phosphorus uptake by cauliflower was significant (Table 7). The individual effect of applied boron on phosphorus uptake by plant was the highest ( $\left.30.05 \mathrm{~kg} \mathrm{ha}^{-1}\right)$ at $\mathrm{B}_{1.3}$ level and it was greater than $\mathrm{B}_{1.95}, \mathrm{~B}_{0.65}$ and $\mathrm{B}_{0}$ levels. The effect of applied phosphorus on phosphorus uptake by plant was the highest $(29.73 \mathrm{~kg}$ 
$h^{-1}$ ) at $\mathrm{P}_{90}$ level and it was significantly higher than $\mathrm{P}_{30}$ but similar to $\mathrm{P}_{60}$ level. The mean phosphorus uptake by cauliflower was increased with increasing levels of boron from $\mathrm{B}_{0}$ to $\mathrm{B}_{1.95}$ and it also increased with increasing level of phosphorus upto $\mathrm{P}_{60}$ level. The maximum phosphorus uptake was recorded at $\mathrm{B}_{1.95} \mathrm{P}_{90}$. The phosphorus uptake from $\mathrm{B}_{1.3} \mathrm{P}_{30}, \mathrm{~B}_{1.3} \mathrm{P}_{60}, \mathrm{~B}_{1.3} \mathrm{P}_{90}, \mathrm{~B}_{1.95} \mathrm{P}_{30}$ and $\mathrm{B}_{1.95} \mathrm{P}_{60}$ were similar to $\mathrm{B}_{1.95} \mathrm{P}_{90}$. Highly significant correlation $\left(r=0.66^{* *}\right)$ was found between plant phosphorus uptake and leaf boron content. The phosphorus uptake by plant with applied phosphorus had quadratic relationship (Figure 1g).

The present results support the findings of several workers (Robertson and Loughman 1974, Loughman 1977) who reported that boron played an important role in phosphate transport across cell membranes. Malewar and Indulkar (1993) revealed that boron containing phosphorus fertilizer showed significant increase in phosphorus uptake as compared to non-boron phosphorus sources. Similar finding was also reported by Randhawa et al (1979) that boron deficiency caused thickening of roots and retarded root elongation, resulting smaller absorbing root surface and reduced phosphorus uptake.

Table 7. Phosphorus uptake by cauliflower as influenced by boron and phosphorus application

\begin{tabular}{lrrrrr}
\hline & \multicolumn{5}{c}{ Phosphorus uptake by cauliflower, $\mathrm{kg} \mathrm{ha}^{-1}$} \\
\cline { 2 - 6 } Treatments & $\mathrm{P}_{0}$ & $\mathrm{P}_{30}$ & $\mathrm{P}_{60}$ & $\mathrm{P}_{90}$ & Mean \\
\cline { 2 - 6 } & $25.85 \mathrm{bcd}$ & $20.83 \mathrm{de}$ & $25.66 \mathrm{bcd}$ & $29.73 \mathrm{bc}$ & $25.52 \mathrm{~b}$ \\
$\mathrm{~B}_{0}$ & $25.26 \mathrm{bcd}$ & $19.51 \mathrm{de}$ & $32.68 \mathrm{~b}$ & $26.12 \mathrm{bcd}$ & $25.89 \mathrm{~b}$ \\
$\mathrm{~B}_{0.65}$ & $30.05 \mathrm{bc}$ & $41.55 \mathrm{a}$ & $41.64 \mathrm{a}$ & $40.01 \mathrm{a}$ & $38.31 \mathrm{a}$ \\
$\mathrm{B}_{1.3}$ & $24.51 \mathrm{~cd}$ & $44.02 \mathrm{a}$ & $43.34 \mathrm{a}$ & $45.75 \mathrm{a}$ & $39.41 \mathrm{a}$ \\
$\mathrm{B}_{1.95}$ & $26.41 \mathrm{~B}$ & $31.48 \mathrm{~B}$ & $35.83 \mathrm{~A}$ & $35.40 \mathrm{~A}$ & 32.27 \\
\hline Mean & $\mathrm{B}$ P 2.33 & $\mathrm{B} 1.16$ & $\mathrm{P} 1.16$ & & \\
$\mathrm{SEM}(0.05)$ & 6.73 & 3.36 & 3.36 & & \\
LSD (0.05) & 12.75 & & & & \\
$\mathrm{CV}, \%$ & & & & & \\
\hline Means followed by the same letter(s) in column and row are not significantly different at \\
5\% level.
\end{tabular}

\section{Soil boron}

The applied boron, phosphorus and their interactions had significant effects on boron status of soil (Table 8). The individual effect of applied boron on soil boron content was the highest $(1.32 \mu \mathrm{g} \mathrm{gm}$ $\left.{ }^{1}\right)$ at $\mathrm{B}_{1.3}$ and it was significantly higher than $\mathrm{B}_{1.95}, \mathrm{~B}_{0.65}$ and $\mathrm{B}_{0}$. The highest boron content of soil was obtained from $B_{1.3} P_{60}$ which was significantly higher than other treatments. The mean soil boron status was increased with increasing levels of applied boron up to $1.3 \mathrm{~kg}$ boron $\mathrm{ha}^{-1}$ and it was also increased with increasing levels of phosphorus up to $\mathrm{P}_{90}$. The $\mathrm{B}_{1.3}$ level had the highest mean soil boron content $\left(1.31 \mu \mathrm{g} \mathrm{gm}^{-1}\right)$ which was significantly higher than $\mathrm{B}_{1.95}, \mathrm{~B}_{0.65}$ and $\mathrm{B}_{0}$ levels. The soil application with $90 \mathrm{~kg} \mathrm{P}_{2} \mathrm{O}_{5} \mathrm{ha}^{-1}$ had the highest mean soil boron content $\left(1.1 \mu \mathrm{g} \mathrm{gm}^{-1}\right)$ which was significantly greater than other levels of boron, including control. 
Table 8. Estimates of soil boron after the crop harvest from boron and phosphorus applied plots

\begin{tabular}{|c|c|c|c|c|c|}
\hline \multirow{2}{*}{ Treatments } & \multicolumn{5}{|c|}{ Soil boron content, $\mu \mathrm{g} \mathrm{gm}^{-1}$} \\
\hline & $\mathrm{P}_{0}$ & $\mathrm{P}_{30}$ & $\mathrm{P}_{60}$ & $\mathrm{P}_{90}$ & Mean \\
\hline $\mathrm{B}_{0}$ & $0.10 \mathrm{i}$ & $0.10 \mathrm{i}$ & $0.10 \mathrm{i}$ & $0.10 \mathrm{i}$ & $0.1 \mathrm{~d}$ \\
\hline $\mathrm{B}_{0.65}$ & $0.60 \mathrm{~g}$ & $0.54 \mathrm{~g}$ & $0.93 \mathrm{e}$ & $1.40 \mathrm{~b}$ & $0.86 b$ \\
\hline $\mathrm{B}_{1.3}$ & $1.32 \mathrm{c}$ & $0.72 \mathrm{f}$ & $1.76 \mathrm{a}$ & $1.45 b$ & $1.31 \mathrm{a}$ \\
\hline $\mathrm{B}_{1.95}$ & $1.20 \mathrm{~d}$ & $0.33 \mathrm{~h}$ & $0.10 \mathrm{i}$ & $1.46 \mathrm{~b}$ & $0.75 \mathrm{c}$ \\
\hline Mean & $0.80 \mathrm{~B}$ & $0.422 \mathrm{D}$ & $0.722 \mathrm{C}$ & $1.103 \mathrm{~A}$ & 0.76 \\
\hline SEM (0.05) & $\mathrm{B} * \mathrm{P} 0.025$ & В 0.012 & P 0.012 & & \\
\hline $\operatorname{LSD}(0.05)$ & 0.074 & 0.037 & 0.037 & & \\
\hline $\mathrm{CV}, \%$ & 5.32 & & & & \\
\hline
\end{tabular}

\section{Soil phosphorus}

The applied phosphorus had significant effect on phosphorus content of soil but the applied boron and their interaction effects were found to be insignificant. The mean available soil phosphorus was the highest $\left(292.7 \mathrm{~kg} \mathrm{ha}^{-1}\right)$ at $\mathrm{P}_{90}$ level which was similar to $\mathrm{P}_{60}$ but significantly higher than $\mathrm{P}_{30}$ and $\mathrm{P}_{0}$ levels. The phosphorus content of soil was the highest at $\mathrm{B}_{0.65} \mathrm{P}_{90}$ and it was similar to treatments consisting of $\mathrm{P}_{90}$ and $\mathrm{P}_{60}$ levels. But they were significantly different from $\mathrm{P}_{0}$ and $\mathrm{P}_{30}$ levels. The mean available soil phosphorus was increased from $P_{0}$ to $P_{90}$ (Table 9) and the $P_{60}$ was similar to $P_{90}$. It seems that the application of $60 \mathrm{~kg} \mathrm{P}_{2} \mathrm{O}_{5} \mathrm{ha}^{-1}$ is judicious for the higher level of soil phosphorus in the soils of Paklihawa. The higher doses of applied phosphorus above $\mathrm{P}_{60}$ level might have reacted with other soil mineral elements and made them unavailable form in soils. 

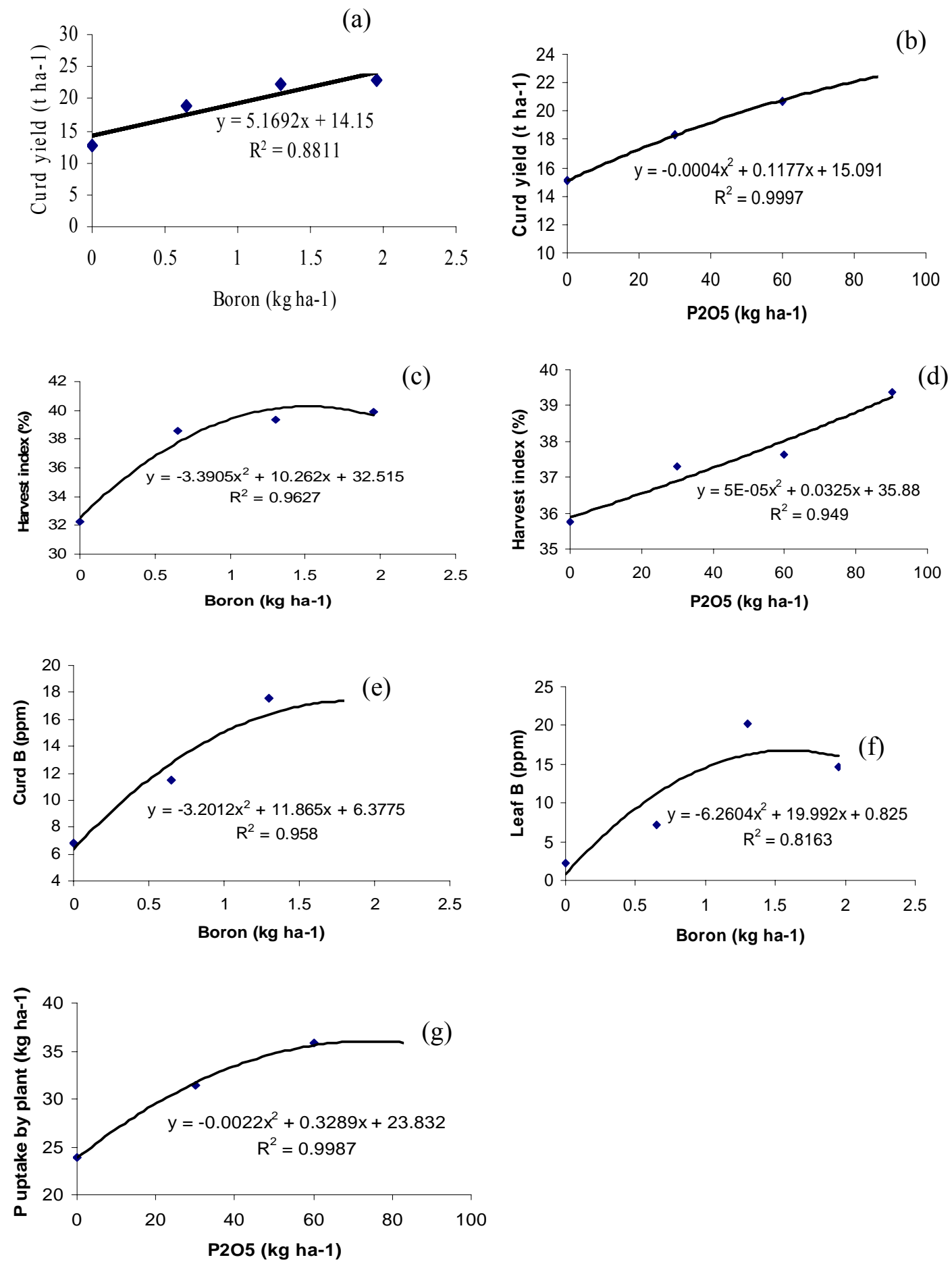

Figure 1. Response of cauliflower characteristics to different levels of boron and phosphorus applied. 
Table 9. Estimates of phosphorus content of soil after the crop harvest from boron and phosphorus applied plots

\begin{tabular}{lrrrrr}
\hline \multirow{2}{*}{ Treatments } & \multicolumn{5}{c}{ Available soil phosphorus $\left(\mathrm{kg} \mathrm{ha}^{-1}\right)$} \\
\cline { 2 - 6 } & $\mathrm{P}_{0}$ & $\mathrm{P}_{30}$ & $\mathrm{P}_{60}$ & $\mathrm{P}_{90}$ & Mean \\
\hline $\mathrm{B}_{0}$ & $224.9 \mathrm{bc}$ & $252.0 \mathrm{abc}$ & $253.4 \mathrm{abc}$ & $291.9 \mathrm{abc}$ & $255.5 \mathrm{~ns}$ \\
$\mathrm{~B}_{0.65}$ & $247.2 \mathrm{bc}$ & $243.8 \mathrm{bc}$ & $301.3 \mathrm{ab}$ & $344.2 \mathrm{a}$ & $284.1 \mathrm{~ns}$ \\
$\mathrm{~B}_{1.3}$ & $200.7 \mathrm{c}$ & $245.2 \mathrm{bc}$ & $276.8 \mathrm{abc}$ & $278.2 \mathrm{abc}$ & $250.2 \mathrm{~ns}$ \\
$\mathrm{~B}_{1.95}$ & $240.9 \mathrm{bc}$ & $244.7 \mathrm{bc}$ & $277.2 \mathrm{abc}$ & $256.7 \mathrm{abc}$ & $254.9 \mathrm{~ns}$ \\
\hline Mean & $228.4 \mathrm{C}$ & $246.4 \mathrm{BC}$ & $277.2 \mathrm{AB}$ & $292.7 \mathrm{~A}$ & 261.19 \\
$\mathrm{SEM}(0.05)$ & $\mathrm{B} * \mathrm{P} 28.31$ & $\mathrm{~B} 14.16$ & $\mathrm{P} 14.16$ & & \\
$\mathrm{LSD}(0.05)$ & 81.77 & 40.88 & 40.88 & & \\
$\mathrm{CV} \%$ & 18.77 & & & & \\
Means followed by the same letter(s) in column and row are not significantly different at \\
5\% level.
\end{tabular}

\section{CONCLUSION}

The study showed that yield of cauliflower was the highest at $1.3 \mathrm{~kg}$ boron with $60 \mathrm{~kg} \mathrm{P}_{2} \mathrm{O}_{5} \mathrm{ha}^{-1}$. The research showed a significant correlation between boron and phosphorus uptake by plants. Similarly, significant correlation between plant boron uptake and soil phosphorus content and vice versa were also observed. Synergistic interaction could be obtained by applying boron and phosphorus within soil and plant system. It can be recommended that $1.3 \mathrm{~kg}$ boron with $60 \mathrm{~kg} \mathrm{P}_{2} \mathrm{O}_{5} \mathrm{ha}^{-1}$ is optimum for cauliflower production at Paklihawa location in Rupandehi district, Nepal but further research is needed to quantify these effects at different locations of the district.

\section{ACKNOWLEDGEMENTS}

The authors thank the Directorate of Research, Institute of Agriculture and Animal Science, Rampur, Chitwan for providing financial support. Paklihawa Campus, Rupandehi is also acknowledged for providing experimental field and necessary resources to conduct the research.

\section{REFERENCES}

Baral DR, TB Khatri-Chhetri and R Adhikari. 1986. Assessment of the needs of secondary and micronutrients for cauliflower in Rampur, Chitwan, Nepal. J. Inst.Agric. and Anim. Sci. 7:21-30.

Bremmer JM and CS Mulvaney. 1982. Nitrogen total. In: Methods of soil analysis, Part II (AL Page, RH Miller and DR Keeney, eds). Amer. Soc. Agron. Pp. 59-69.

Fujimoto T. 1998. Current status of soil fertility in Nepal (Part 2). In: Soil science programs at a glance. Soil Testing and Service Section, Crop Development Division, Department of Agriculture, Ministry of Agriculture, Lalitpur, Nepal. Pp. 26-28. 
Gaines TP and GA Mitchell. 1979. Boron determination in plant tissue by Azomethine-H method. Comm.Soil Sci. Plant Anal. 10:1099-1108.

Gee GW and JW Bauder. 1986. Particle size analysis. In: Methods of soil analysis, Part I (A Klute, ed). Amer. Soc. Agron. Pp. 11-59.

Gomez KA and AA Gomez. 1984. Statistical procedures for agricultural research. A Wiley Interscience Publication, John Wiley and Sons, New York.

Gupta UC. 1993. Factors affecting boron uptake by plants in boron and its role in crop production. Crop Science. Pp. 88-104.

Jaishy SN, T Fujimoto and R Manandhar. 2000. Current status of soil fertility in Nepal. In: Proceeding of $3^{\text {rd }}$ National Conference on Science and Technology. RONAST, Nepal. Pp. 1097-1104.

Kotur SC and S Kumar. 1989. Response of cauliflower to boron in Chhotanagpur region. Ind. J. Agric. Sci. 59:640-644.

Loughman BC. 1977. Metabolic factors and utilization of phosphate by plants. Ciba Foundation Symposium. 57:155-174.

Malewar GU and BS Indulkar. 1993. Effect of phosphorus and boron on cauliflower. Ind. Soc. Veg. Sci. 20(1):26-30.

Mengel K and EA Kirkby. 1987. Principles of plant nutrition. Second Edition. International Potash Institute, Berne, Switzerland.

Mishra DP. 1972. Sambalpur cauliflower needs boron. Intensive Agriculture 10:11-12.

Mitra SK. 1990. Cauliflower. In: Nutrition of vegetable crops (SK Mitra, MK Sadhu and TK Bose, eds). Naya Prokash, Calcutta, India. Pp. 133-148.

Moore KP. 1991. Determination of phosphorus in plant tissue by colorimetry. In: Plant analysis reference procedures for the Southern region of the United States (CO Plank, ed). Southern Cooperative Bull, 368, University of Georgia, Athens, GA. Pp. 29-32.

Nepal Agri-Business Promotion and Statistics Division. 2004. Statistical information on Nepalese Agriculture. Agri-Business Promotion and Statistics Division, Ministry of Agriculture and Co-operatives, Singha Durbar, Kathmandu, Nepal.

Olsen SR, CV Cole, FS Watanabe and HC Dean. 1954. Estimation of available phosphorus in soils by extraction with sodium bicarbonate. USDA. 939p.

Pandey UC, UC Shukla and K Singh. 1974. Effect of zinc and boron on yield and quality of cauliflower (Brassica oleracea var. botrytis). Haryana J. Hort. Sci. 3:201-206.

Pratt PF. 1965. Potassium. In: Methods of soil analysis. Part II: chemical and microbial properties (CA Black, ed). Amer. Soc. Agron., Madison, USA. Pp. 1005-1049.

Randhawa KS and AS Bhail. 1976. Effect of nitrogen, phosphorus and potassium on cauliflower. Ind. J. Hort. 33:83-91. 
Randhawa NS, DL Dev, PN Takkar and NS Pasricha. 1979. Phosphorus micronutrient interaction in soils and plants. In: Phosphorus in soils, crops and fertilizers. Ind. Soc. Soil Sci. New Delhi, India. Pp. 58-72.

Robertson GA and BC Loughman. 1974. Modification of phosphate transport in Vicia faba by boron deficiency, growth inhibitors and metabolic inhibitors. In: Membrane transport in plants (U Zimmerman and J Dainty, eds). Springer Verlag, New York. Pp. 444-449.

Stoyanov DV. 1971. Conditions for the boron nutrition of tobacco in Bulgeria. $J$. Agrochemical 6:99.

Thakur OP, PP Sharma and KK Singh. 1991. Effect of nitrogen and phosphorus with and without boron on curd yield and stalk rot incidence in cauliflower. Ind. Soc. Veg. Sci. $18(2): 115-121$.

Walkley A and IA Black. 1934. An examination of direct method for determining organic matter and a proposed modification of the chromic acid titration method. J. Soil Sci. Soc. Amer. 37:29-38. 